\title{
Hydrogen Energy Demand Growth Prediction and Assessment (2021-2050) Using a System Thinking and System Dynamics Approach
}

\author{
Talal Yusaf ${ }^{1, * \mathbb{D}}$, Mohamd Laimon ${ }^{2}$, Waleed Alrefae ${ }^{3}$, Kumaran Kadirgama ${ }^{4}$, Hayder A. Dhahad ${ }^{5}$ (D), \\ Devarajan Ramasamy ${ }^{6}$ (D), Mohd Kamal Kamarulzaman ${ }^{7}$ (D) and Belal Yousif ${ }^{8}$ (D)
}

\section{check for}

updates

Citation: Yusaf, T.; Laimon, M.; Alrefae, W.; Kadirgama, K.; Dhahad, H.A.; Ramasamy, D.; Kamarulzaman, M.K.; Yousif, B. Hydrogen Energy Demand Growth Prediction and Assessment (2021-2050) Using a System Thinking and System Dynamics Approach. Appl. Sci. 2022, 12, 781. https://doi.org/10.3390/ app12020781

Academic Editor: Andreas Sumper

Received: 28 December 2021

Accepted: 11 January 2022

Published: 13 January 2022

Publisher's Note: MDPI stays neutral with regard to jurisdictional claims in published maps and institutional affiliations.

Copyright: (C) 2022 by the authors. Licensee MDPI, Basel, Switzerland. This article is an open access article distributed under the terms and conditions of the Creative Commons Attribution (CC BY) license (https:// creativecommons.org/licenses/by/ $4.0 /)$.
1 School of Engineering and Technology, Central Queensland University, Brisbane, QLD 4008, Australia 2 Engineering Faculty, Al-Hussein Bin Talal University, Ma'an 71111, Jordan; u1093176@umail.usq.edu.au 3 Mechanical Engineering Technology Department, The Public Authority of Applied Education and Training (PAAET), Adailiyah P.O. Box 23167, Kuwait; waleed_alrefae@hotmail.com

4 Faculty of Mechanical and Automotive Engineering Technology, Universiti Malaysia Pahang, Pekan 26600, Pahang, Malaysia; kumaran@ump.edu.my

5 Mechanical Engineering Department, University of Technology, Baghdad P.O. Box 18310, Iraq; Hader.A.Dhahad@uotechnology.edu.iq

6 College of Engineering, Universiti Malaysia Pahang, Pekan 26600, Pahang, Malaysia; deva@ump.edu.my

7 Automotive Engineering Centre, Universiti Malaysia Pahang, Pekan 26600, Pahang, Malaysia; kamalkz@hotmail.com

8 School of Engineering, The University Southern Queensland, Toowoomba, QLD 4350, Australia; belal.yousif@usq.edu.au

* Correspondence: t.yusaf@cqu.edu.au

\begin{abstract}
Adoption of hydrogen energy as an alternative to fossil fuels could be a major step towards decarbonising and fulfilling the needs of the energy sector. Hydrogen can be an ideal alternative for many fields compared with other alternatives. However, there are many potential environmental challenges that are not limited to production and distribution systems, but they also focus on how hydrogen is used through fuel cells and combustion pathways. The use of hydrogen has received little attention in research and policy, which may explain the widely claimed belief that nothing but water is released as a by-product when hydrogen energy is used. We adopt systems thinking and system dynamics approaches to construct a conceptual model for hydrogen energy, with a special focus on the pathways of hydrogen use, to assess the potential unintended consequences, and possible interventions; to highlight the possible growth of hydrogen energy by 2050 . The results indicate that the combustion pathway may increase the risk of the adoption of hydrogen as a combustion fuel, as it produces $\mathrm{NO}_{x}$, which is a key air pollutant that causes environmental deterioration, which may limit the application of a combustion pathway if no intervention is made. The results indicate that the potential range of global hydrogen demand is rising, ranging from 73 to $158 \mathrm{Mt}$ in 2030, 73 to 300 Mt in 2040, and 73 to $568 \mathrm{Mt}$ in 2050, depending on the scenario presented.
\end{abstract}

Keywords: hydrogen energy; hydrogen demand; hydrogen fuel cell pathway; hydrogen combustion pathway; emissions; nitrogen oxides; renewable alternative fuel; systems thinking; system dynamics

\section{Introduction}

Hydrogen is a promising alternative to fossil fuels in many applications. Some of these applications are the domain of hydrogen energy, and no other alternatives can compete with hydrogen, such as heavy and long-distance transport (e.g., heavy-duty trucks, ships, and planes), as well as energy-intensive manufacturing sectors (e.g., ferrous and nonferrous metals, petroleum refining, chemicals, and cement). With the current technology, these sectors are difficult to electrify, and other alternatives (e.g., bio energy) cannot cope with demand. Hence, decarbonisation of these sectors will remain a challenge. Therefore, 
adoption of hydrogen as a replacement for a fossil fuel could be a major step towards decarbonising and fulfilling the needs of the energy sector.

Hydrogen is an abundant (the most abundant element in the universe), efficient, reliable, clean, non-toxic, and renewable fuel, and it has a very high energy content (about three times as much as gasoline and natural gas, and almost seven times that of coal) [1-3]. Hydrogen's entire process has four stages: (1) resources, (2) systems, (3) pathways of use, and (4) end use, as shown in Figure 1. Hydrogen can be produced by diverse energy resources, such as RE and fossil fuels. If it is produced by RE, it is called green hydrogen, if it is produced by fossil fuels with Carbon Capture Storage (CCS), it is called blue hydrogen, and if it is produced by fossil fuels without CCS, it is called grey hydrogen [4]. Three systems are involved: production systems, storage systems, and delivery systems. Production systems include many routes; the most prevalent are: Steam Methane Reforming (SMR), which is the process in which methane extracted from natural gas is heated by steam to generate hydrogen [5]; coal gasification, which is the process in which Carbon Dioxide $\left(\mathrm{CO}_{2}\right)$ is generated by adding air to the coal through combustion. Carbon dioxide then reacts with the rest of the carbon in the coal to form carbon monoxide, and in the final process, carbon monoxide reacts with steam, generating hydrogen [6]; electrolysis of water, which is the process of using electricity to decompose water into oxygen and hydrogen [7]. Storage systems also include many routes, of which the most common storage systems are: as a compressed gas in high-pressure gas cylinders; as a liquid in cryogenic tanks; as a solid by reacting with metals or chemical compounds or being stored in an alternative chemical form. Delivery systems are through three main methods: gaseous pipelines; pressurized tube trailers; cryogenic liquid tankers [8]. Hydrogen energy can be used through two key pathways: fuel cells and combustion [9]. Fuel cells produce electricity, while combustion is used in boilers and engines [10]. End use includes a large number of: chemicals (e.g., methanol, and ammonia), industry (refinery, steel, and cement), residential and commercial (e.g., blending into natural gas pipelines), mobility (e.g., fuel cells electric vehicle), power (e.g., power generation by turbine and storage as a backup power in fuel cells or tank storage), and space applications (e.g., rocket fuel).

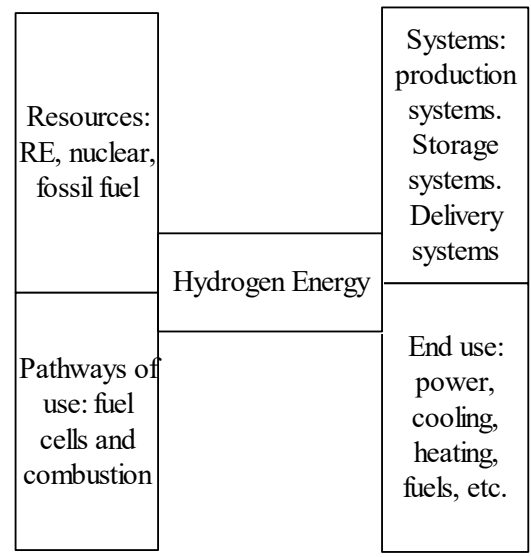

Figure 1. Hydrogen entire process stages.

Previous efforts have focused, mainly, on hydrogen production resources and systems [11-17]. For example, Dincer et al. [11] assessed innovative hydrogen production methods under various criteria. Hosseini et al. [12] highlighted the state-of-the-art hydrogen production technologies using renewable and sustainable energy resources. Acar et al. [18] provided a review on sustainability of hydrogen production systems. Niaz et al. [14] focused on various hydrogen producing and storing methods for creating a hydrogen economy. When considering the impact of hydrogen on the environment, the focus rests on issues related to the leakage of hydrogen [19-24]. For example, Li et al. [19] and Shen et al. [20] investigated the safety of hydrogen fuel cells by a numerical simulation of hydrogen leakage from fuel cell ship and vehicle, while Gye et al. [21] assessed the risk 
of an urban hydrogen refuelling station. The pathways of hydrogen use have received little attention in research or policy, which may be explained by the common belief that nothing but water is released as a by-product when hydrogen energy is used, a belief that is only true for the fuel cells pathway. Burning of hydrogen in the combustion pathway can produce Nitrogen Oxides $\left(\mathrm{NO}_{x}\right)$, which have something in common between hydrogen and fossil fuel when burned at high temperatures [25-27]. $\mathrm{NO}_{\mathrm{x}}$ is a harmful air pollutant that can be formed in all fuel-air mixed in high flames (above $1300^{\circ} \mathrm{C}$ ); less than $750{ }^{\circ} \mathrm{C}$ no $\mathrm{NO}_{\mathrm{x}}$ is formed [26,28]. This may pose a risk to the future of hydrogen energy as a combustion fuel. On the other hand, previous studies have employed different approaches to explore the future of hydrogen energy demand, such as the Geographic Information System (GIS) method [29-31], the Optimal Power Flow (OPF) technique [32], and the mathematical model [33].

However, there is a need to understand the dynamics underlying interactions among the components of any complex system, which is the domain of systems thinking and system dynamics approaches, as applications of these approaches in the hydrogen energy sector have been largely absent. Further, there is a need to focus on fields and/or sectors in which only hydrogen can play a vital role compared with other alternatives, which is missing in many previous studies, and has been taken into consideration in this paper. Exploring the future of hydrogen energy demand and highlighting the risks that may affect the sector are of paramount importance to understand the transition to a hydrogen economy.

The aim of this study is twofold: (1) using a systems thinking approach to build a conceptual model for hydrogen energy, with a special focus on the pathways of hydrogen use, to assess the potential consequences that could lead to unintended impacts, and possible interventions; (2) using a system dynamics approach to highlight the possible demand growth of hydrogen energy until 2050. The demand meant here is the global demand, and it will be linked to a case study of a country that may be a leader in hydrogen production in the foreseen future [34-36]. Australia's path will be compared with the global path, hence potential opportunities need to be seized. Australia is one of the world's largest exporters of coal and natural gas, and by 2032, with excessive fossil fuel extraction, coal will be the only fossil fuel resource that Australia totally relies on [37]; hence, Australia should think about an export alternative of energy, and hydrogen would be a suitable alternative, as the current infrastructure used for gas can also be used for hydrogen [38-40].

\section{Hydrogen Recent Development}

Hydrogen, today, is gaining unprecedented traction. This is clearly seen through: the increasing demand, which has grown more than threefold since 1975; the mega projects being implemented; the increasing of policies that directly support investment in hydrogen technologies; the mandates and policy incentives that directly support hydrogen; the global spending on hydrogen energy research [41,42].

\section{Hydrogen Economy}

Nearly every day, there is a new update on the use of hydrogen in transportation and energy. The potential for Hydrogen to X (H2X) to easily merge with present transportation and energy systems, while dramatically lowering air pollution (zero-carbon emission at point of use) [2,43], is fascinating. Simultaneously, human reliance on fossil fuels is responsible for anything from oil spills to ozone threats to climate change [44,45]. The political plan likewise prioritizes the guarantee of price stability and energy supply [46]. These factors are driving the world's transition far from a fossil fuels economy and toward a greener hydrogen economy. The Hydrogen Economy or Hydrogen Energy System is a theoretical concept of a system in which hydrogen is the primary energy source. In 1970, John Bockris was the earliest one to introduce the phrase "hydrogen economy" at the General Motors (GM) Technical Center presentation and during a hydrogen meeting in Miami [47]. 
The main objective of a hydrogen economy is to produce hydrogen primarily from readily available energy sources in order to replace fossil fuels currently used in transportation, industry, domestic, and commercial applications. The hydrogen economy has been presented as a highly refined and long-term solution to the world's interrelated difficulties, such as (i) world environment concern, (ii) natural resource depletion, (iii) food shortages and malnutrition in third-world countries, and (iv) the world's growing population. Despite the fact that the issues connected with the fossil fuel economy are serious and overwhelming, successful growth of the hydrogen economy will result in significant benefits for the environmental, energy supplies, economic, and end users [48]. Besides the benefits, rapid transition from fossil fuel energy to a hydrogen energy system has been slowed by substantial socioeconomic, technological, and scientific challenges. The extraordinarily low density of hydrogen makes storage a crucial issue during the transfer [49]. Although chemical and refinery industries commonly utilize hydrogen, its costs for production, storage, and delivery are too expensive and undesirable for the majority of energy applications [50].

Furthermore, the great advantages of the hydrogen economy are so exciting that policymakers from all over the world are spending heavily in improving the energy system's prospects [14]. The European Commission's High Level Group on Hydrogen and Fuel Cell Technologies proposed, in 2003, that the European Union achieve a hydrogen-based economy by 2050 and anticipates that, by 2040, 35\% of new manufactured automobiles would be powered by zero carbon hydrogen [51]. The Energy Efficiency and Renewable Energy, Fossil Energy, Nuclear Energy, and Science Offices of the US Department of Energy, on the other hand, recommended that transition to hydrogen-powered fuel cell automobiles take place around 2020 [52].

The hydrogen economy has been intensively explored, according to the research; various roadmap reports, case studies, and reviews have been documented, summarizing the main achievements and the function of hydrogen's potential in the energy sector [53-55]. For the purpose of completeness, researchers demonstrates an increasing attention in exploring the social consequences, policy issues, environmental impact, and techno-economic of hydrogen economy [18]. As a result, a number of national and international organizations have been established to educate the policymakers, companies, and public in order to develop a foundation and promote preparations for the hydrogen economy age. Several examples are shown in Table 1.

Table 1. National and international hydrogen organization.

\begin{tabular}{cc}
\hline Location & Organization \\
\hline Africa & The Hydrogen South Africa $($ HySA) \\
Australia & The Australian Association for Hydrogen Energy $($ AAHE) \\
Canada & Canadian hydrogen and fuel cell industry \\
Europe & Hydrogen Europe \\
Global & Hydrogen Council \\
Spain & Hydrogen Foundation \\
Global & IEA Hydrogen \\
Global & The Fuel Cell and Hydrogen Energy Association (FCHEA) \\
Global/USA & The International Centre for Hydrogen Energy Technologies $($ ICHET) \\
UNIDO & National Hydrogen Association $(N H A)$ \\
USA & The U.S. DOE Hydrogen and Fuel Cells Program \\
USA & Renewable Hydrogen Council \\
WA-Australia & Thernational Association for Hydrogen Energy (IAHE)
\end{tabular}

The hydrogen economy is not presented as a substitute to existing energy vectors in the world scale but rather, as a compliment in the aspect of a smart and low-carbon strategy for certain purposes and areas [53]. As a result, the transformation to a worldwide "hydrogen economy" is unlikely to occur in the near future [44]. Recent publically funded 
R\&D initiatives, cost-effectiveness, policies, and the development of a hydrogen system, on the other hand, will undoubtedly contribute to making this dream a reality [56,57].

Renewable hydrogen (i.e., Green Hydrogen), production from renewable energy resources, as well as the development of all corners of square-shaped Hydrogen Square (HydS) (shown in Figure 2) seems to be a promising way to comply with a $100 \%$ renewable electric grid and expanding to a $100 \%$ renewable energy supply and, hence, a hydrogen economy [58,59]. The literature shows consensus on green hydrogen has the potential to decarbonise a large range of industrial applications or serve as a clean energy carrier for storing renewable energy, utilised in a variety of applications [59,60]. However, parallel development in the four corners of the HydS is essential for the green pathways to become technoeconomically feasible.

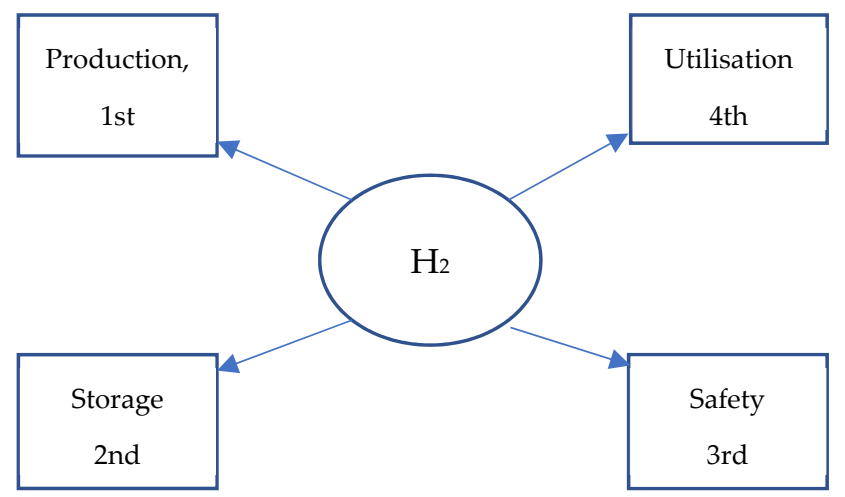

Figure 2. Hydrogen Square (HydS): four corners model.

Hydrogen economy seems achievable when a 100\% renewable electric grid complied and expanded to a $100 \%$ renewable energy supply though the development of all corners of HydS, production from renewable energy resources, and renewable hydrogen (i.e., Green Hydrogen) [61,62]. Green hydrogen has the ability to decarbonise a wide range of economic uses or act as a clean energy carrier for storing renewable energy to be be used in a lot of areas [63]. Nevertheless, for green pathways to become technoeconomically viable, simultaneous growth at the four corners of the HydS is required.

\section{Exergy Destruction}

Exergy is the amount of work that can be done with a given amount of energy. Exergy is the highest theoretical useable energy that can be extracted from an energy resource or a substance that is subjected to an almost reversible technique from its starting condition until it is returned to its natural condition. Exergy is determined by a total of parameters that can be equal to zero (in an equilibrium state with the surroundings), and it is reliant on the relative state of a system and its ambient conditions [64]. Exergy is an indicator that measures how much a system deviates from equilibrium with its surroundings. Exergy is a term that encompasses both the qualitative and quantitative aspects of energy. Any irreversible occurrence results in exergy losses, resulting in process exergy destruction (loss of useful work) or elevated energy consumption from whichever source the energy was acquired from. The Gouy-Stodola theorem connects exergy destruction to total entropy production in a system:

$$
\dot{E}=T_{0} \dot{S}_{g e n}
$$

where $\dot{E}$ is the exergy destruction, commonly known as loss of useful work, $T_{0}$ is the environment's reference temperature, and $\dot{S}_{g e n}$ is the system's total entropy production.

Limited numbers of scientists and researchers are reported in prediction and modelling of hydrogen energy demands. A hybrid energy system for electricity and hydrogen generation is theoretically conceived and implemented to an island, Bozcaada, by Kalinci et al. [65]. Exergy, energy, and techniques are used to undertake a thermodynamic evalua- 
tion. The Hybrid Optimization Model for Electric Renewable (HOMER) software examines the theoretical structure from the perspectives of energy load distributions and the economy. The study's analytical scenarios are based on the stand-alone island model. The converter, hydrogen tank, polymer electrolyte membrane fuel cell (PEMFC), electrolyser, wind turbines, and photovoltaic (PV) array are all included in the model. The magnitudes and locations of system inefficiencies are determined using exergy and energy assessments. The studies are mostly performed for the primary equipment under dynamically changing environmental and operational circumstances. There are also hourly distributions of varying exergy and energy rates shown. As a result, the PV array's daily average exergy and energy efficiencies are $14.26 \%$ and $13.31 \%$, respectively. In addition, the efficiency values for the electrolyser equipment is calculated as exergy at $60.26 \%$ and energy at $59.68 \%$, while the wind turbine is determined as exergy at $50.12 \%$ and energy at $46 \%$, respectively.

\section{Research Method}

\subsection{Developing Systems Thinking and System Dynamics Models for Hydrogen Energy}

Systems thinking and system dynamics approaches are used to deal with complexity in systems. Systems thinking represents qualitative modelling, where the end goal is to develop a conceptual model that presents the dynamic interaction between system components. System dynamics represents quantitative modelling, where the end goal is to build a simulation model to simulate the dynamic relationships between the components. The steps of systems thinking are: problem articulation and formulating dynamic hypotheses (conceptual model), while the steps of systems dynamics are: formulating a simulation model, validating/testing, policy design, and evaluation, as shown in Figure 3. Understanding, analysing, and improving the performance of complex systems are the aims of using systems thinking and system dynamics approaches.

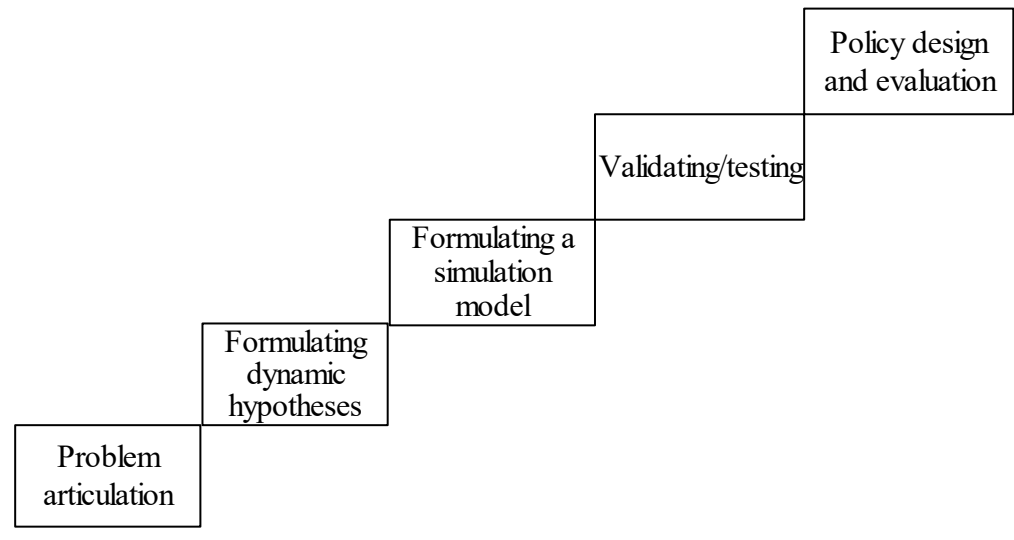

Figure 3. The steps for systems thinking and systems dynamics.

A conceptual model for hydrogen energy was constructed using a Causal Loop Diagram (CLD). A CLD consists of variables and arrows that present the causal relationships between the variables. The arrows within a CLD link variables together to form either reinforcing (positive) denoted by $\mathrm{R}$, or balancing (negative) denoted by $\mathrm{B}$ feedback loops. $\mathrm{R}$ feedback loops create exponential growth or decline over time, while B feedback loops act to stabilize system behaviour over time. A system dynamics model for hydrogen demand was constructed in order to calculate the hydrogen demand for different sectors where hydrogen is dominant. Systems dynamics consist of stocks, flows, and auxiliary variables. The stock is a variable that accumulates or depletes over time through flow into or out of the stock, which leads to feedback that can cause changes, either accelerating (reinforcing feedback) or balancing out (balancing feedback). Reinforcing feedback (positive) arises when a stock causes changes, leading to further growth; balancing feedback (negative) arises when a stock causes changes leading to slower growth. A stock responds to changes 
by its flows, while the flows are controlled by stock and auxiliary variables. Figure 4 represents an example for feedback loops and stock-flow model.

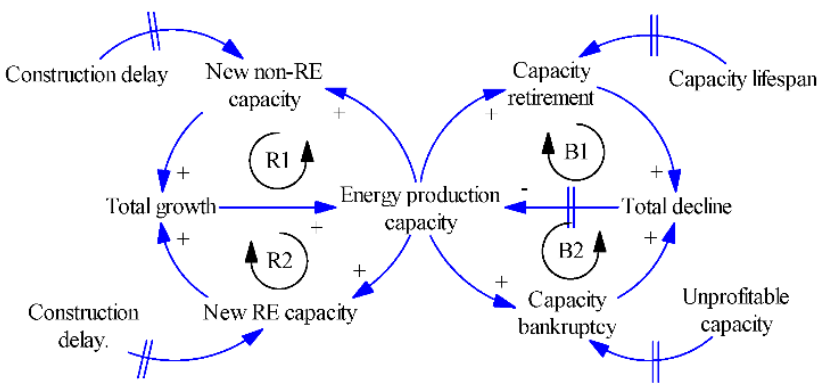

(a)

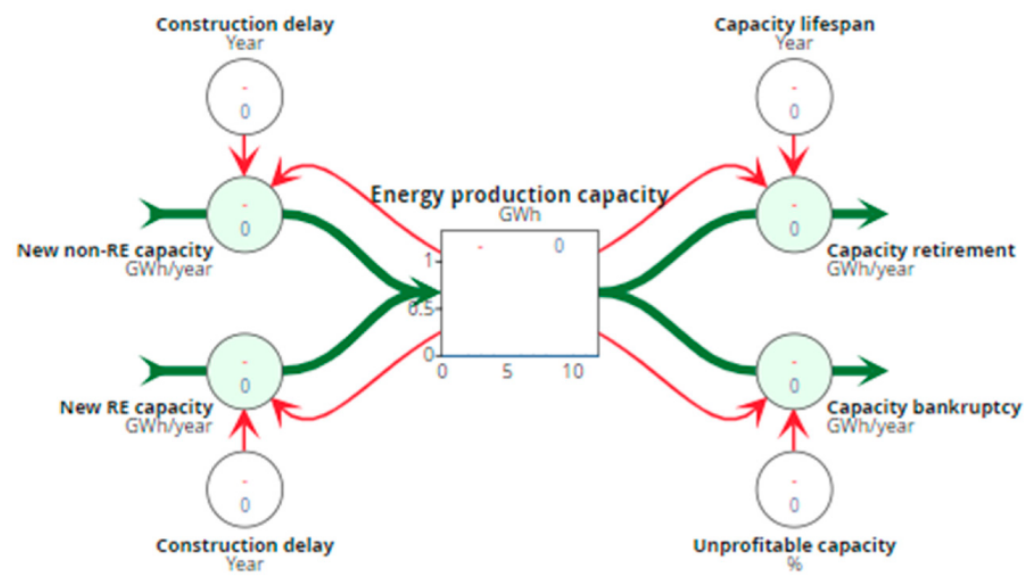

(b)

Figure 4. Feedback loops (a) and stock-flow model (b) [37].

\subsection{Leverage Points and System Archetypes}

CLD is a powerful tool that goes beyond understanding of a dynamic and complex system; it can also be used to uncover leverage points (e.g., intervention strategies) that lead to improve system performance. Leverage points are not easy to identify, but System Archetypes (SAs) may help uncover them. SAs are highly aggregated situations in isolation, derived from the main model. There are many archetypes, but the most common are Limits to Growth and Fixes that Fail archetypes. The Limits to Growth archetype represents situations in which growth driven by $\mathrm{R}$ loops is followed by stagnation or decline driven by $\mathrm{B}$ loops. In that case, leverage points are latent in B loops; thus, limiting factors that change the behaviour must be identified and changed. The Fixes that Fail archetype relates to fixes where unintended, and often harmful, consequences resulted from well intended actions. Thus, a long-term fix should be maintained, and short-term quick fixes should be avoided.

\section{Results}

\subsection{The Conceptual Model of Hydrogen Energy}

The CLD of hydrogen energy is shown in Figure 5, which contains seven reinforcing loops (R1 to R7) and three balancing loops (B1 to B3). The CLD highlights the interrelationships among the main components of the variables. The variables involved and the key message conveyed by each loop are summarized in Table 2 and as in Appendix A (Table A1). 


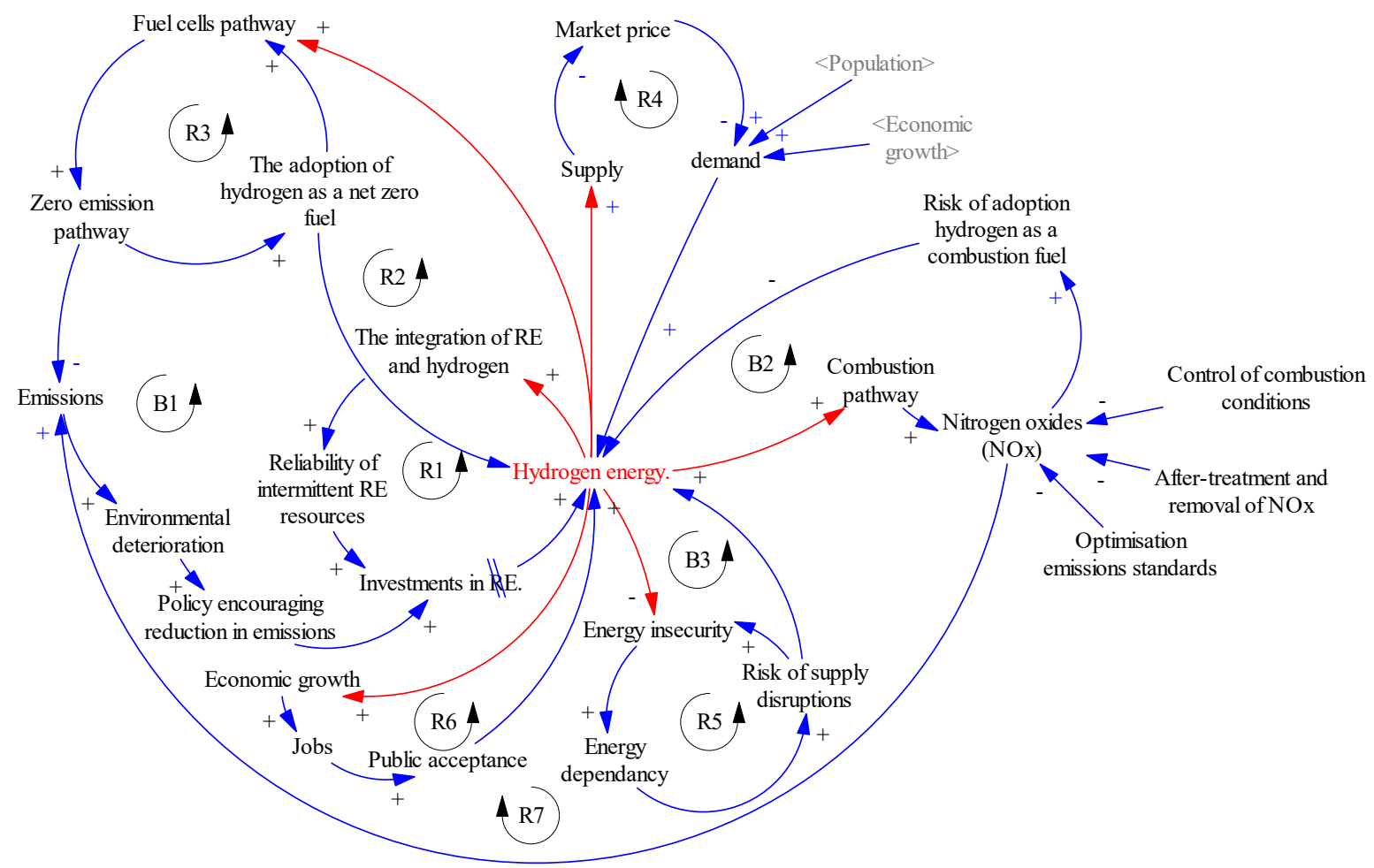

Figure 5. The CLD of hydrogen energy. A positive polarity $(+)$ means that the two variables change in the same direction, while a negative polarity (-) means that they move in the opposite direction. Double bars $(\mathrm{I} \mid \mathrm{l})$ indicate a time delay between the two variables. R represents Reinforcing loops, while B represents Balancing loops.

Table 2. The feedback loops within Figure 5.

\begin{tabular}{|c|c|c|c|}
\hline Loop Name & $\begin{array}{l}\text { Feedback } \\
\text { Loop }\end{array}$ & Variables Involved & Key Message \\
\hline \multirow{7}{*}{ Reinforcing } & $\mathrm{R} 1$ & $\begin{array}{l}\text { Hydrogen energy } \rightarrow+\text { The integration of } R E \text { and hydrogen } \rightarrow+\text { Reliability } \\
\text { of intermittent RE resources } \rightarrow+\text { Investments in } R E \rightarrow+\text { Hydrogen energy }\end{array}$ & Growth of hydrogen and RE \\
\hline & $\mathrm{R} 2$ & $\begin{array}{c}\text { Hydrogen energy } \rightarrow+\text { Fuel cells pathway } \rightarrow+\text { Zero emission pathway } \rightarrow+ \\
\text { Hydrogen energy } \rightarrow+\text { The adoption of hydrogen as a net zero fuel } \rightarrow+ \\
\text { Hydrogen energy }\end{array}$ & Emissions mitigation \\
\hline & $\mathrm{R} 3$ & $\begin{array}{c}\text { Fuel cells pathway } \rightarrow+\text { Zero emission pathway } \rightarrow+\text { The adoption of } \\
\text { hydrogen as a net zero fuel } \rightarrow+\text { Fuel cells pathway }\end{array}$ & Emissions mitigation \\
\hline & $\mathrm{R} 4$ & $\begin{array}{c}\text { Hydrogen energy } \rightarrow+\text { Supply } \rightarrow-\text { Market price } \rightarrow-\text { demand } \rightarrow+ \\
\text { Hydrogen energy }\end{array}$ & Supply-demand \\
\hline & $\mathrm{R} 5$ & $\begin{array}{c}\text { Energy insecurity } \rightarrow+\text { Energy dependancy } \rightarrow+\text { Risk of supply disruptions } \\
\qquad+ \text { Energy insecurity }\end{array}$ & Energy insecurity \\
\hline & R6 & $\begin{array}{c}\text { Hydrogen energy } \rightarrow+\text { Economic growth } \rightarrow+\text { Jobs } \rightarrow+\text { Public acceptance } \\
\rightarrow+\text { Hydrogen energy }\end{array}$ & Economic growth \\
\hline & R7 & $\begin{array}{l}\text { Emissions } \rightarrow+\text { Environmental deterioration } \rightarrow+\text { Policy encouraging } \\
\text { reduction in emissions } \rightarrow+\text { Investments in } \mathrm{RE} \rightarrow+\text { Hydrogen energy } \rightarrow+ \\
\text { Combustion pathway } \rightarrow+\text { Nitrogen oxides }\left(\mathrm{NO}_{\mathrm{x}}\right) \rightarrow+\text { Emissions }\end{array}$ & Emissions \\
\hline \multirow{3}{*}{ Balancing } & B1 & $\begin{array}{c}\text { Hydrogen energy } \rightarrow+\text { Fuel cells pathway } \rightarrow+\text { Zero emission pathway } \rightarrow \\
- \text { Emissions } \rightarrow+\text { Environmental deterioration } \rightarrow+\text { Policy encouraging } \\
\text { reduction in emissions } \rightarrow+\text { Investments in } R E \rightarrow+\text { Hydrogen energy }\end{array}$ & Emissions mitigation \\
\hline & B2 & $\begin{array}{l}\text { Hydrogen energy } \rightarrow+\text { Combustion pathway } \rightarrow+\text { Nitrogen oxides }\left(\mathrm{NO}_{\mathrm{x}}\right) \rightarrow \\
+ \text { Risk of adoption hydrogen as a combustion fuel } \rightarrow-\text { Hydrogen energy }\end{array}$ & $\begin{array}{l}\text { Risk of adoption hydrogen as } \\
\text { a combustion fuel }\end{array}$ \\
\hline & B3 & $\begin{array}{c}\text { Hydrogen energy } \rightarrow-\text { Energy insecurity } \rightarrow+\text { Energy dependency } \rightarrow+ \\
\text { Risk of supply disruptions } \rightarrow+\text { Hydrogen energy }\end{array}$ & Energy insecurity \\
\hline
\end{tabular}




\subsection{System Archetypes}

The first SA seen in the conceptual model is 'Limits to Growth'. This archetype consists of a reinforcing (R1) and a balancing loop (B2), as illustrated in Figure 6a. Hydrogen energy increases the reliability of intermittent RE resources (wind and solar power), and this, in turn, will increase investments in RE. Reliability of supply is one of the most crucial challenges of RE intermittent resources. Using hydrogen energy as a backup power in RE intermittent resources will enhance flexibility and solve the uncertainty of RE. On the other hand, hydrogen as a combustion fuel may increase $\mathrm{NO}_{\mathrm{x}}$, which, in turn, may affect the adoption of hydrogen as a combustion fuel. Flame temperature is the limiting factor that may affect hydrogen growth as a combustion fuel. Reducing or controlling the limiting factor may minimize $\mathrm{NO}_{\mathrm{x}}$ emissions.

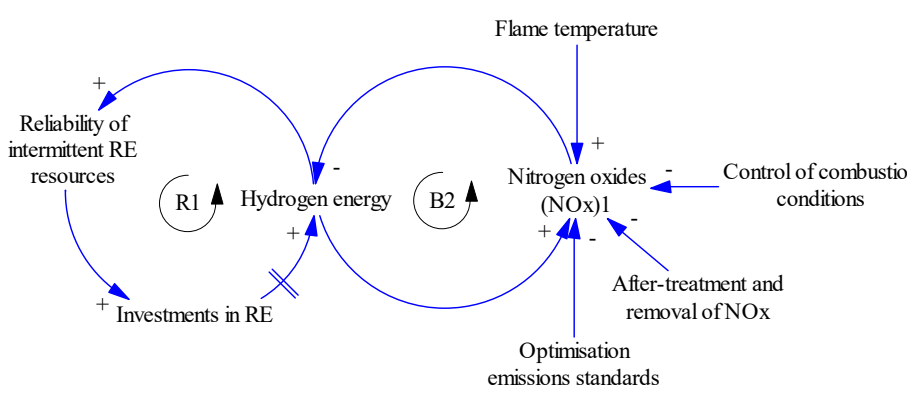

(a)

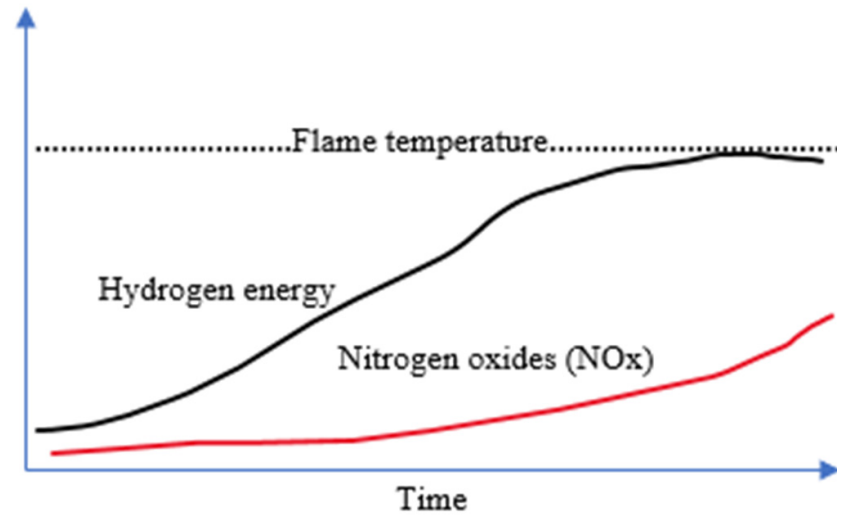

(b)

Figure 6. Structure (a) and behavioural graph (b) of the Limits to Growth.

The second SA is 'Fixes that Fail'. This archetype consists of reinforcing (R7) and a balancing loop (B1), as illustrated in Figure 7a. To mitigate emissions, the government is investing in hydrogen energy (loop B1, Figure 6a). While investing in hydrogen is important to mitigate $\mathrm{CO}_{2}$ emissions, hydrogen as a combustion fuel may lead to further emissions $\left(\mathrm{NO}_{\mathrm{x}}\right)$, which will, in turn, increase the net of emissions (represented by loop R7).

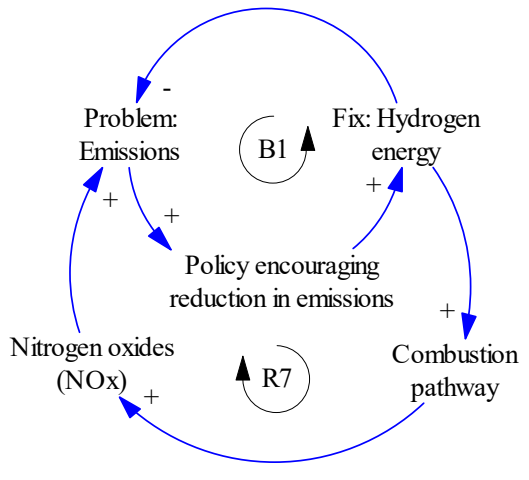

(a)

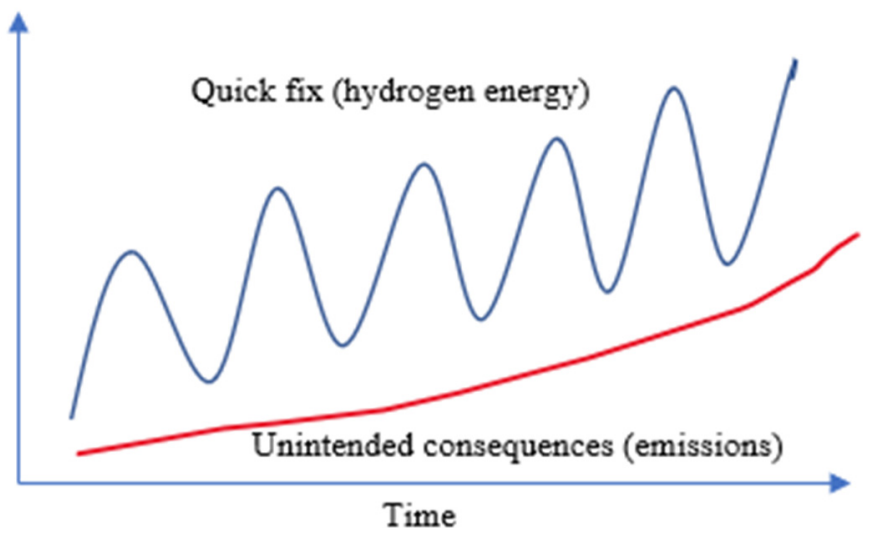

(b)

Figure 7. Structure (a) and behavioural graph (b) of the Fixes that Fail archetype.

\subsection{The System Dynamics Model of Hydrogen Demand}

The system dynamics model of hydrogen demand is shown in Figure 8. In regard to the global hydrogen demand, four scenarios have been taken into consideration until 2050: 
(1) a no-growth scenario (current production); (2) a base case scenario that represents the current trend (current growth), and no dramatic changes are assumed, and the base year is 2019, while 2020 has been excluded, due to drops in demand amid the global pandemic (COVID 19); (3) average growth, based on average growth over the last ten years; (4) best case scenario assumes that hydrogen will be the fuel of choice for: grid electrical supply as a back-up capacity ( $20 \%$ of total energy demand); heavy and long-distance transport ( $20 \%$ of total energy demand); energy-intensive manufacturing sector ( $20 \%$ of total energy demand); ammonia production (41 $\mathrm{MtH}$ in 2019). These sectors have been selected, as hydrogen can play a vital role in them. The same sectors have been targeted in the case study, considering the current production of these sectors in the Australian context until 2050. The only difference is that the Australian gas sector as an important export has been added to the model to be replaced by hydrogen in the future. The data have been extracted from the "Australian Energy Statistics"-Australian Energy Update report 2019-2020 [66]. It is updated each year and consists of detailed historical energy consumption, production, and trade statistics and balances. The unit used in the report for all energy sources is PJ, however the total hydrogen demand calculated in the model is converted from PJ to KWh to Mt. In this study, all the different forms of energy are put into the same units, and one-to-one conversion rate is used. This is used by many sources and it is the scientific way to compare and summarize energies [67]. Figure 9 shows the potential global demand for hydrogen for the four scenarios. Figure 10 shows the potential hydrogen demand in the Australian context compared to the global demand for the four scenarios.

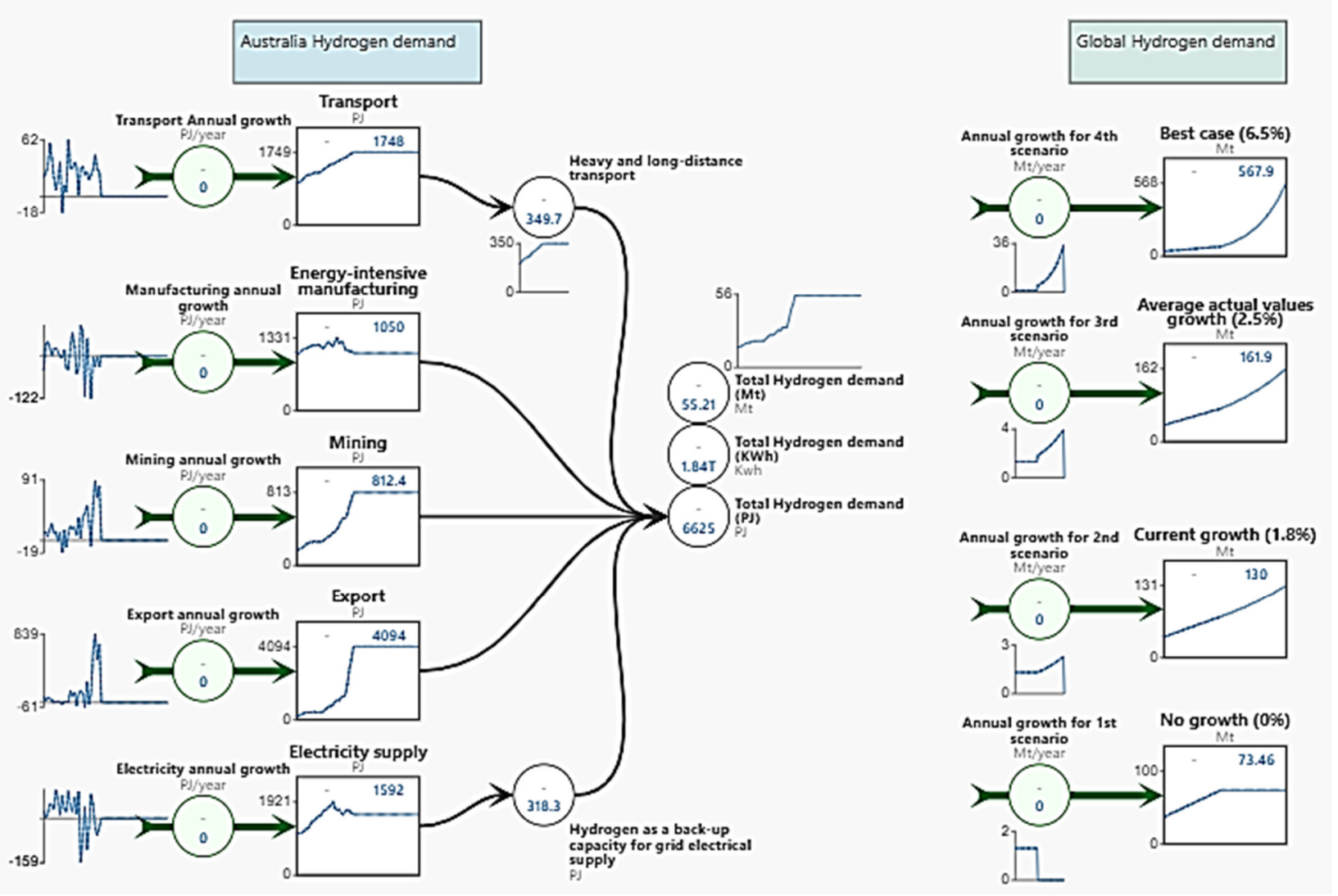

Figure 8. The system dynamics model of hydrogen demand. 


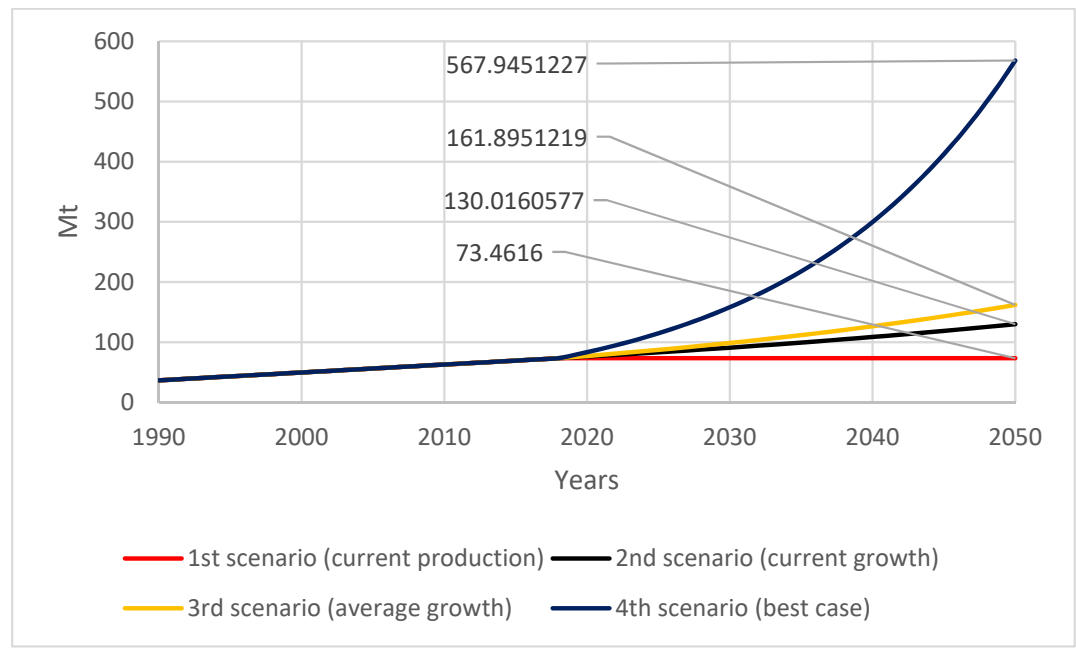

Figure 9. The potential global demand for hydrogen for the four scenarios.

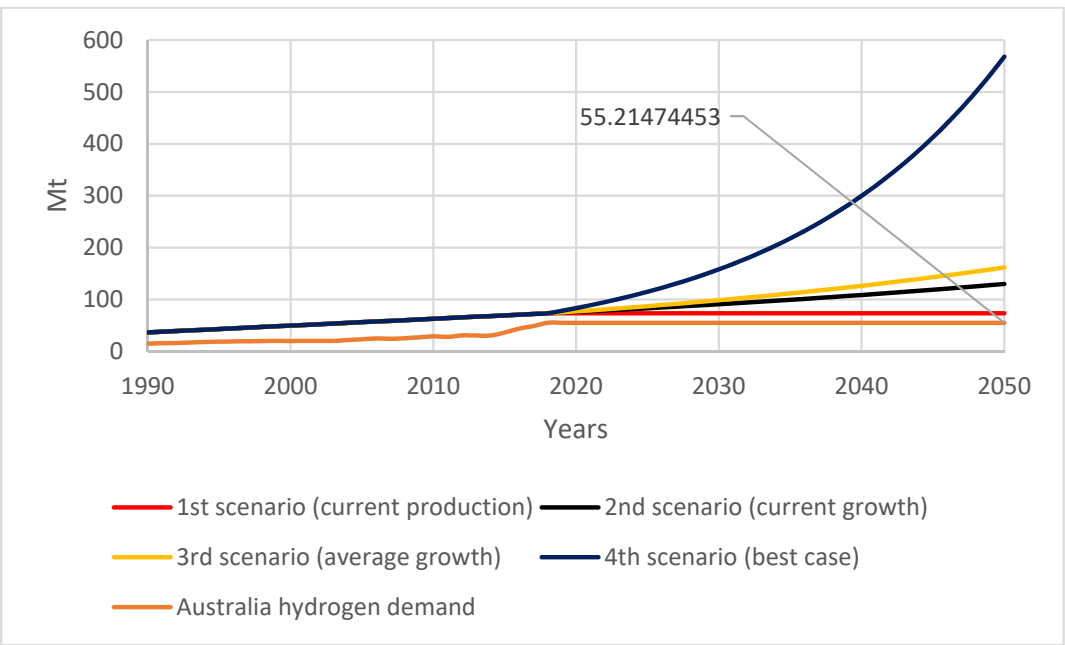

Figure 10. The potential hydrogen demand in the Australian context compared to the global demand for the four scenarios.

\section{Model Validating/Testing}

The validating of system dynamics models generally involves structural and behavioural tests. Structural tests assess whether the model's structure represents the real system. Behavioural tests assess whether the model provides a sensible output behaviour. Regarding the structural tests, dependency and unit consistency test, laws of conservation and accumulation test, and negative stock test have been applied. Dependency and check unit consistency was performed using the "dependency tracking" feature in the software used (Silico) [68] to check the relationship between parameters and track their units. The laws of conservation and accumulation test implies that the value of the stock must equal the sum of inflows minus the sum of outflows. The negative stock test implies that the stock cannot go below zero.

In relation to the behavioural tests, the model should include a number of real/actual values (historical time-periods). The current study used a historical time series consisting of 30 years from 1990-2019.

\section{Discussion}

The findings indicate that hydrogen energy is important for supporting energy security and renewable energy, zero emission pathway, and economic growth. Hydrogen is an ideal option for an energy-intensive manufacturing sector, grid electrical supply, heavy 
and long-distance transport, gas networks, and a key ingredient for producing chemicals such as ammonia. Ammonia is an effective hydrogen storage, and it can be used by extracting its stored hydrogen or used directly as fuel. Ammonia can be produced from many different types of energy sources, including renewables, fossil fuels and surplus energy [69]. Recently, Ammonia and hydrogen production from algae is gaining attention as high total energy efficiency was reported to be achieved [70]. However, there are many potential environmental challenges that are not limited to production and distribution systems, but they also relate to how the hydrogen is used through fuel cells and combustion pathways, a concept which has received little attention in research and policy. Combustion pathway may increase the risk of adoption of hydrogen as a combustion fuel (loop B2), as it produces $\mathrm{NO}_{\mathrm{x}}$, a key air pollutant that causes environmental deterioration (loop R7), which may limit the application of the combustion pathway [71].

Through the CLD we have constructed, two SAs were revealed, namely, limits to growth and fixes that fail-Figures 6 and 7. Both SAs indicate that the combustion pathway may undermine the use of hydrogen as a combustion fuel if no intervention is made. These interventions are pointed to in the CLD, namely, control of combustion conditions, aftertreatment and removal, and optimization emissions standards. These interventions can reduce $\mathrm{NO}_{\mathrm{x}}$, but they have downsides too: control of combustion conditions may affect performance; after-treatment and removal may increase cost; optimization emissions standards require extensive testing of performance of new engineered boilers, and engines before deployment to be approved by the new standards [26]. Considering the aforementioned is of paramount importance, as it may have an effect on hydrogen demand in the future.

The findings indicate that the range of global hydrogen demand is from 73 to $158 \mathrm{Mt}$ in 2030, 73 to 300 in 2040, and 73 to $568 \mathrm{Mt}$ in 2050, depending on the scenario presented. Revealing and defining these scenarios will help countries to leverage global energy opportunities. One of these countries is Australia, which is planning to become a global player in hydrogen energy. According to our findings, hydrogen demand could reach $21 \mathrm{Mt}$ for domestic use, if Australia adopted hydrogen in its fields (100\% of heavy and long-distance transport, $100 \%$ of energy-intensive manufacturing, $100 \%$ of mining, and $20 \%$ of grid electrical supply as a backup capacity); 34 Mt for export, if replacing gas exports with hydrogen in the future. Australia is one of the world's biggest exporters of coal and natural gas, and it is looking at replacing fossil fuel exports with an alternative; this alternative could not be better than hydrogen. It is expected that, by 2030 and 2040, hydrogen will be one of the preferred technologies [72,73].

\section{Conclusions}

Adoption of hydrogen energy as a future fuel requires a comprehensive understanding of its components and interactions, and intervention scenarios that may change system behaviour. This is the domain of systems thinking and system dynamics approaches. We used systems thinking and system dynamics approaches to examine the behaviour and trends of hydrogen energy through different possible scenarios. A systems thinking approach was used to build a conceptual model for hydrogen energy, with a special focus on the pathways of hydrogen use, to assess the potential consequences that could lead to unintended impacts and possible interventions. A system dynamics approach was used to highlight the growth of the possible global demand of hydrogen energy until 2050, and it has been linked to Australia's potential hydrogen demand in order to leverage global energy opportunities.

Findings indicate that hydrogen global demand is rising and ranges from $73 \mathrm{Mt}$ (pessimistic case) to $568 \mathrm{Mt}$ (optimistic case) by 2050. For countries seeking to be leaders in hydrogen production like Australia, this is motivating news, as adopting hydrogen for some sectors (heavy and long-distance transport, energy-intensive manufacturing, mining, and grid electrical supply) and replacing fossil fuel (mainly gas) with hydrogen, for export, means that the Australian hydrogen demand could reach $55 \mathrm{Mt}$. 
This study provides insights and information on the future of hydrogen energy demand and highlights the risks that may affect the sector, which may assist policy decision makers to understand and test their options for the transition to a hydrogen economy, which may enable more effective decisions and/or policy changes to obtain much better outcomes and avoid undesirable ones. Regarding limitations of the work, energy demand growth has been taken as an exogenous variable, although other studies may take it as an endogenous variable. Further, future studies can implement the model in other countries, as the proposed model can be used in any country. There are significant benefits for the transition to a hydrogen economy. However, the supply side includes many variables, which will be a focus of the next paper.

Author Contributions: Conceptualization, T.Y. and W.A.; methodology, K.K. and D.R.; software, M.L.; validation, H.A.D. and M.K.K.; formal analysis, B.Y. All authors have read and agreed to the published version of the manuscript.

Funding: This research received no external funding.

Institutional Review Board Statement: Not applicable.

Informed Consent Statement: Not applicable.

Data Availability Statement: Not applicable.

Conflicts of Interest: The authors declare no conflict of interest.

\section{Appendix A}

Table A1. Parameters used in the simulation model. The model produces behaviours over time graphs from 1990 to 2050. The software used is Silico (https:/ / silico.app/).

\begin{tabular}{|c|c|c|}
\hline \multicolumn{3}{|c|}{ Australia Hydrogen Demand } \\
\hline Variable Name & Units & Parameter Value \\
\hline Transport Annual growth & $\mathrm{PJ} /$ year & Real/actual values (historical values) from 1990 to 2019. After 2019 no growth is assumed \\
\hline Transport & PJ & Accumulation of transport Annual growth \\
\hline Heavy and long-distance transport & & “Transport" 0.2 \\
\hline Manufacturing annual growth & $\mathrm{PJ} /$ year & Real/actual values (historical values) from 1990 to 2019. After 2019 no growth is assumed \\
\hline Energy-intensive manufacturing & PJ & Accumulation of manufacturing annual growth \\
\hline Mining annual growth & $\mathrm{PJ} /$ year & Real/actual values (historical values) from 1990 to 2019. After 2019 no growth is assumed \\
\hline Mining & PJ & Accumulation of mining annual growth \\
\hline Export annual growth & PJ/year & Real/actual values (historical values) from 1990 to 2019 . After 2019 no growth is assumed \\
\hline Export & PJ & Accumulation of export annual growth \\
\hline Electricity annual growth & $\mathrm{PJ} /$ year & Real/actual values (historical values) from 1990 to 2019. After 2019 no growth is assumed \\
\hline Electricity supply & PJ & Accumulation of electricity annual growth \\
\hline Hydrogen as a back-up capacity for grid electrical supply & PJ & "Electricity supply"*0.2 \\
\hline Total Hydrogen demand (PJ) & PJ & $\begin{array}{l}\text { "Export" + "Heavy and long-distance transport" + "Hydrogen as a back-up capacity for } \\
\text { grid electrical supply" + "Energy-intensive manufacturing" + "Mining" }\end{array}$ \\
\hline Total Hydrogen demand (KWh) & KWh & “Total Hydrogen demand $(\mathrm{PJ})$ ” $* 277800000$ \\
\hline Total Hydrogen demand (Mt) & Mt & (“Total Hydrogen demand (KWh)" /33.33)/1000000000 \\
\hline \multicolumn{3}{|c|}{ Global Hydrogen demand } \\
\hline Annual growth for 1st scenario & Mt/year & Real/actual values (historical values) from 1990 to 2019. After 2019 no growth is assumed \\
\hline No growth $(0 \%)$ & Mt & Accumulation of annual growth for 1st scenario \\
\hline Annual growth for 2nd scenario & Mt/year & Real/actual values (historical values) from 1990 to 2019. After $20191.8 \%$ growth is assumed \\
\hline Current growth $(1.8 \%)$ & Mt & Accumulation of annual growth for 2nd scenario \\
\hline Annual growth for 3 rd scenario & Mt/year & Real/actual values (historical values) from 1990 to 2019. After $20192.5 \%$ growth is assumed \\
\hline Average actual values growth $(2.5 \%)$ & Mt & Accumulation of annual growth for 3rd scenario \\
\hline Annual growth for 4 th scenario & $\mathrm{Mt} /$ year & Real/actual values (historical values) from 1990 to 2019. After $20196.5 \%$ growth is assumed \\
\hline Best case $(6.5 \%)$ & Mt & Accumulation of annual growth for 4 th scenario \\
\hline
\end{tabular}




\section{References}

1. Zohuri, B. Hydrogen energy. In Cryogenics and Liquid Hydrogen Storage: Challenges and Solutions for a Cleaner Future; Springer: New York, NY, USA, 2019; pp. 121-139.

2. Abe, J.O.; Popoola, A.; Ajenifuja, E.; Popoola, O. Hydrogen energy, economy and storage: Review and recommendation. Int. J. Hydrogen Energy 2019, 44, 15072-15086. [CrossRef]

3. Weger, L.B.; Leitao, J.; Lawrence, M.G. Expected impacts on greenhouse gas and air pollutant emissions due to a possible transition towards a hydrogen economy in German road transport. Int. J. Hydrogen Energy 2021, 46, 5875-5890. [CrossRef]

4. Atilhan, S.; Park, S.; El-Halwagi, M.M.; Atilhan, M.; Moore, M.; Nielsen, R.B. Green hydrogen as an alternative fuel for the shipping industry. Curr. Opin. Chem. Eng. 2021, 31, 100668. [CrossRef]

5. Yang, J.-H.; Yoon, Y.; Ryu, M.; An, S.-K.; Shin, J.; Lee, C.-J. Integrated hydrogen liquefaction process with steam methane reforming by using liquefied natural gas cooling system. Appl. Energy 2019, 255, 113840. [CrossRef]

6. Li, J.; Cheng, W. Comparative life cycle energy consumption, carbon emissions and economic costs of hydrogen production from coke oven gas and coal gasification. Int. J. Hydrogen Energy 2020, 45, 27979-27993. [CrossRef]

7. Lamy, C.; Millet, P. A critical review on the definitions used to calculate the energy efficiency coefficients of water electrolysis cells working under near ambient temperature conditions. J. Power Sources 2020, 447, 227350. [CrossRef]

8. Tarhan, C.; Çil, M.A. A study on hydrogen, the clean energy of the future: Hydrogen storage methods. J. Energy Storage 2021, 40, 102676. [CrossRef]

9. Vinoth Kanna, I.; Paturu, P. A study of hydrogen as an alternative fuel. Int. J. Ambient Energy 2020, 41, 1433-1436. [CrossRef]

10. Hosseini, S.E.; Butler, B. An overview of development and challenges in hydrogen powered vehicles. Int. J. Green Energy 2020, 17, 13-37. [CrossRef]

11. Dincer, I.; Acar, C. Innovation in hydrogen production. Int. J. Hydrogen Energy 2017, 42, 14843-14864. [CrossRef]

12. Hosseini, S.E.; Wahid, M.A. Hydrogen production from renewable and sustainable energy resources: Promising green energy carrier for clean development. Renew. Sustain. Energy Rev. 2016, 57, 850-866. [CrossRef]

13. Acar, C.; Beskese, A.; Temur, G.T. Sustainability analysis of different hydrogen production options using hesitant fuzzy AHP. Int. J. Hydrogen Energy 2018, 43, 18059-18076. [CrossRef]

14. Niaz, S.; Manzoor, T.; Pandith, A.H. Hydrogen storage: Materials, methods and perspectives. Renew. Sustain. Energy Rev. 2015, 50, 457-469. [CrossRef]

15. Zhang, F.; Zhao, P.; Niu, M.; Maddy, J. The survey of key technologies in hydrogen energy storage. Int. J. Hydrogen Energy 2016, 41, 14535-14552. [CrossRef]

16. Ren, J.; Musyoka, N.M.; Langmi, H.W.; Mathe, M.; Liao, S. Current research trends and perspectives on materials-based hydrogen storage solutions: A critical review. Int. J. Hydrogen Energy 2017, 42, 289-311. [CrossRef]

17. Nagpal, M.; Kakkar, R. An evolving energy solution: Intermediate hydrogen storage. Int. J. Hydrogen Energy 2018, 43, 12168-12188. [CrossRef]

18. Acar, C.; Dincer, I. Review and evaluation of hydrogen production options for better environment. J. Clean. Prod. 2019, 218, 835-849. [CrossRef]

19. Li, F.; Yuan, Y.; Yan, X.; Malekian, R.; Li, Z. A study on a numerical simulation of the leakage and diffusion of hydrogen in a fuel cell ship. Renew. Sustain. Energy Rev. 2018, 97, 177-185. [CrossRef]

20. Shen, Y.; Zheng, T.; Lv, H.; Zhou, W.; Zhang, C. Numerical Simulation of Hydrogen Leakage from Fuel Cell Vehicle in an Outdoor Parking Garage. World Electr. Veh. J. 2021, 12, 118. [CrossRef]

21. Gye, H.-R.; Seo, S.-K.; Bach, Q.-V.; Ha, D.; Lee, C.-J. Quantitative risk assessment of an urban hydrogen refueling station. Int. J. Hydrogen Energy 2019, 44, 1288-1298. [CrossRef]

22. Chen, J.; Gong, Y.; Jiang, T.-H.; Pan, A.-X.; Wang, S.-H.; Yang, Z.-G. Failure analysis on abnormal leakage of TP321 stainless steel pipe of medium temperature shifting gas in hydrogen production system. Eng. Fail. Anal. 2021, 125, 105413. [CrossRef]

23. Moradi, R.; Groth, K.M. Hydrogen storage and delivery: Review of the state of the art technologies and risk and reliability analysis. Int. J. Hydrogen Energy 2019, 44, 12254-12269. [CrossRef]

24. Li, W.; Kou, H.; Zeng, X.; Cui, Y.; Chen, H.; Wang, F. Numerical simulations on the leakage and diffusion of tritium. Fusion Eng. Des. 2020, 159, 111749. [CrossRef]

25. Ingenito, A.; Agresta, A.; Andriani, R.; Gamma, F. NOx reduction strategies for high speed hydrogen fuelled vehicles. Int. J. Hydrogen Energy 2015, 40, 5186-5196. [CrossRef]

26. Lewis, A.C. Optimising air quality co-benefits in a hydrogen economy: A case for hydrogen-specific standards for NOx emissions. Environ. Sci. Atmos. 2021, 1, 201-207. [CrossRef]

27. Wang, D.; Ji, C.; Wang, S.; Yang, J.; Wang, Z. Numerical study of the premixed ammonia-hydrogen combustion under enginerelevant conditions. Int. J. Hydrogen Energy 2021, 46, 2667-2683. [CrossRef]

28. Yu, Q.; Hendrix, Y.; Lorencik, S.; Brouwers, H. Field study of NOx degradation by a mineral-based air purifying paint. Build. Environ. 2018, 142, 70-82. [CrossRef]

29. Ni, J.; Johnson, N.; Ogden, J.M.; Yang, C.; Johnson, J. Estimating hydrogen demand distribution using geographic information systems (GIS). In Proceedings of the National Hydrogen Association (NHA) Annual Hydrogen Conference, Entitled "Partnering for the Global Hydrogen Future", Washington, DC, USA, 29 March-1 April 2005. 
30. Melendez, M.; Milbrandt, A. Regional Consumer Hydrogen Demand and Optimal Hydrogen Refueling Station Siting; National Renewable Energy Lab. (NREL): Golden, CO, USA, 2008.

31. Rahmouni, S.; Settou, N.; Negrou, B.; Gouareh, A. GIS-based method for future prospect of hydrogen demand in the Algerian road transport sector. Int. J. Hydrogen Energy 2016, 41, 2128-2143. [CrossRef]

32. Carr, S.; Premier, G.C.; Guwy, A.J.; Dinsdale, R.M.; Maddy, J. Hydrogen storage and demand to increase wind power onto electricity distribution networks. Int. J. Hydrogen Energy 2014, 39, 10195-10207. [CrossRef]

33. Kim, J.; Lee, Y.; Moon, I. Optimization of a hydrogen supply chain under demand uncertainty. Int. J. Hydrogen Energy 2008, 33 , 4715-4729. [CrossRef]

34. Burdon, R.; Palmer, G.; Chakraborty, S. National Hydrogen Strategysubmission; Energy Transition Hub: Canberra, Australia, 2019.

35. Feitz, A.J.; Coghlan, R.; Tenthorey, E. Prospective Hydrogen Production Regions of Australia; Geoscience: Symonston, Australia, 2019.

36. Low, D.; Rodger, A.; Gallagher, B.; Sharma, P. Is hydrogen Asia's new energy commodity? Opportunities and challenges for Australia. APPEA J. 2020, 60, 468-472. [CrossRef]

37. Laimon, M.; Mai, T.; Goh, S.; Yusaf, T. Energy Sector Development: System Dynamics Analysis. Appl. Sci. 2020, 10, 134. [CrossRef]

38. Witkowski, A.; Rusin, A.; Majkut, M.; Stolecka, K. Analysis of compression and transport of the methane/hydrogen mixture in existing natural gas pipelines. Int. J. Press. Vessel. Pip. 2018, 166, 24-34. [CrossRef]

39. Gondal, I.A. Hydrogen integration in power-to-gas networks. Int. J. Hydrogen Energy 2019, 44, 1803-1815. [CrossRef]

40. Timmerberg, S.; Kaltschmitt, M. Hydrogen from renewables: Supply from North Africa to Central Europe as blend in existing pipelines-Potentials and costs. Appl. Energy 2019, 237, 795-809. [CrossRef]

41. Altarazi, Y.S.; Talib, A.R.A.; Gires, E.; Yu, J.; Lucas, J.; Yusaf, T. Performance and exhaust emissions rate of small-scale turbojet engine running on dual biodiesel blends using Gasturb. Energy 2021, 232, 120971. [CrossRef]

42. Shadidi, B.; Najafi, G.; Yusaf, T. A Review of Hydrogen as a Fuel in Internal Combustion Engines. Energies 2021, 14, 6209. [CrossRef]

43. Dawood, F.; Anda, M.; Shafiullah, G. Hydrogen production for energy: An overview. Int. J. Hydrogen Energy 2020, 45, 3847-3869. [CrossRef]

44. Mulder, M.; Perey, P.; Moraga, J.L. Outlook for a Dutch hydrogen market. Univerity Gron. 2019, 16, 2019. Available online: https:/ / www.rug.nl/ceer/blog/ceer_policypaper_5_web.pdf (accessed on 7 January 2022).

45. Kamarulzaman, M.K.; Hafiz, M.; Abdullah, A.; Chen, A.F.; Awad, O.I. Combustion, performances and emissions characteristics of black soldier fly larvae oil and diesel blends in compression ignition engine. Renew. Energy 2019, 142, 569-580. [CrossRef]

46. $\quad$ Dicks, A.L.; Rand, D.A. Fuel Cell Systems Explained; John Wiley \& Sons: Hoboken, NJ, USA, 2018.

47. Chen, Y.-T.; Hsu, C.-W. The key factors affecting the strategy planning of Taiwan's hydrogen economy. Int. J. Hydrogen Energy 2019, 44, 3290-3305. [CrossRef]

48. Wang, Y.; Huang, R.; Liu, Z. The Relationship between Structural Intensity and Sound Field Characteristics of Cylindrical Shells. Procedia Eng. 2017, 214, 41-49. [CrossRef]

49. Eftekhari, A.; Fang, B. Electrochemical hydrogen storage: Opportunities for fuel storage, batteries, fuel cells, and supercapacitors. Int. J. Hydrogen Energy 2017, 42, 25143-25165. [CrossRef]

50. Sadhasivam, T.; Kim, H.-T.; Jung, S.; Roh, S.-H.; Park, J.-H.; Jung, H.-Y. Dimensional effects of nanostructured $\mathrm{Mg} / \mathrm{MgH}_{2}$ for hydrogen storage applications: A review. Renew. Sustain. Energy Rev. 2017, 72, 523-534. [CrossRef]

51. Hydrogen Energy and Fuel Cells: A Vision of Our Future: Final Report of the High Level Group; European Commission, DirectorateGeneral for Research: Brussel, Belgium, 2003; Volume 20719, Available online: https: / www.fch.europa.eu/sites/default/files / documents/hlg_vision_report_en.pdf (accessed on 27 December 2021).

52. Durbin, D.J.; Malardier-Jugroot, C. Review of hydrogen storage techniques for on board vehicle applications. Int. J. Hydrogen Energy 2013, 38, 14595-14617. [CrossRef]

53. Parra, D.; Valverde, L.; Pino, F.J.; Patel, M.K. A review on the role, cost and value of hydrogen energy systems for deep decarbonisation. Renew. Sustain. Energy Rev. 2019, 101, 279-294. [CrossRef]

54. Dias, V.; Pochet, M.; Contino, F.; Jeanmart, H. Energy and economic costs of chemical storage. Front. Mech. Eng. 2020, 6, 21. [CrossRef]

55. Mah, A.X.Y.; Ho, W.S.; Bong, C.P.C.; Hassim, M.H.; Liew, P.Y.; Asli, U.A.; Kamaruddin, M.J.; Chemmangattuvalappil, N.G. Review of hydrogen economy in Malaysia and its way forward. Int. J. Hydrogen Energy 2019, 44, 5661-5675. [CrossRef]

56. Robledo, C.B.; Oldenbroek, V.; Abbruzzese, F.; van Wijk, A.J.M. Integrating a hydrogen fuel cell electric vehicle with vehicle-to-grid technology, photovoltaic power and a residential building. Appl. Energy 2018, 215, 615-629. [CrossRef]

57. Acar, C.; Dincer, I. Investigation of a novel photoelectrochemical hydrogen production system. Chem. Eng. Sci. 2019, 197, 74-86. [CrossRef]

58. Lyseng, B.; Niet, T.; English, J.; Keller, V.; Palmer-Wilson, K.; Robertson, B.; Rowe, A.; Wild, P. System-level power-to-gas energy storage for high penetrations of variable renewables. Int. J. Hydrogen Energy 2018, 43, 1966-1979. [CrossRef]

59. Oldenbroek, V.; Verhoef, L.A.; van Wijk, A.J.M. Fuel cell electric vehicle as a power plant: Fully renewable integrated transport and energy system design and analysis for smart city areas. Int. J. Hydrogen Energy 2017, 42, 8166-8196. [CrossRef]

60. Badea, G.; Naghiu, G.S.; Giurca, I.; Aşchilean, I.; Megyesi, E. Hydrogen Production Using Solar Energy—Technical Analysis. Energy Procedia 2017, 112, 418-425. [CrossRef] 
61. Simonis, B.; Newborough, M. Sizing and operating power-to-gas systems to absorb excess renewable electricity. Int. J. Hydrogen Energy 2017, 42, 21635-21647. [CrossRef]

62. Olivier, P.; Bourasseau, C.; Bouamama, P.B. Low-temperature electrolysis system modelling: A review. Renew. Sustain. Energy Rev. 2017, 78, 280-300. [CrossRef]

63. Australia's National Hydrogen Strategy. 2019. Available online: https://www.h2knowledgecentre.com/content/government622 (accessed on 27 December 2021).

64. Szargut, J.; Morris, D.R.; Steward, F.R. Exergy Analysis of Thermal, Chemical, and Metallurgical Processes; US Department of Energy: Washington, DC, USA, 1987.

65. Kalinci, Y.; Dincer, I.; Hepbasli, A. Energy and exergy analyses of a hybrid hydrogen energy system: A case study for Bozcaada. Int. J. Hydrogen Energy 2017, 42, 2492-2503. [CrossRef]

66. Australian Government; Department of Industry, Science, Energy and Resources. Australian Energy Statistics. Available online: https:/ / www.energy.gov.au/government-priorities/energy-data/australian-energy-statistics (accessed on 31 December 2021).

67. MacKay, D. Sustainable Energy —Without the Hot Air; UIT Cambridge: London, UK, 2008.

68. Silico. Available online: https://www.silicoai.com/ (accessed on 29 December 2021).

69. Aziz, M.; Wijayanta, A.T.; Nandiyanto, A.B.D. Ammonia as effective hydrogen storage: A review on production, storage and utilization. Energies 2020, 13, 3062. [CrossRef]

70. Wijayanta, A.T.; Aziz, M. Ammonia production from algae via integrated hydrothermal gasification, chemical looping, $\mathrm{N}_{2}$ production, and $\mathrm{NH}_{3}$ synthesis. Energy 2019, 174, 331-338. [CrossRef]

71. Guo, H.; Zhou, S.; Zou, J.; Shreka, M. A Numerical Investigation on De-NOx Technology and Abnormal Combustion Control for a Hydrogen Engine with EGR System. Processes 2020, 8, 1178. [CrossRef]

72. Steyn, J. Hydrogen for Vehicular Transport. In Proceedings of the AIIT 2nd International Congress on Transport Infrastructure and Systems in a changing world (TIS ROMA 2019), Rome, Italy, 23-24 September 2019.

73. Horvath, S.; Fasihi, M.; Breyer, C. Techno-economic analysis of a decarbonized shipping sector: Technology suggestions for a fleet in 2030 and 2040. Energy Convers. Manag. 2018, 164, 230-241. [CrossRef] 